\title{
Behold and Empower
}

\section{Anto $\mathrm{Sr} \mathrm{T}^{*}$ \\ Jubilee Mission College of Nursing, India}

*Corresponding author: Sr Tresa Anto, Jubilee Mission College of Nursing, Holy Family

Quarters, thrissur, Trichur, Kerala, 680005, India, Tel: 9745686254; Email:

\section{Editorial}

Volume 3 Issue 1

Received Date: February 12, 2019

Published Date: February 18, 2019

srtresaanto@gmail.com

\section{Editorial}

We are observing World cancer day on February $4^{\text {th }}$ and world sick day February $11^{\text {th }}$.when we face sufferings, the word comfort is very important in our life. Comfort, it is the need of the hour, sick people need to be comforted; how can we comfort a disturbed person with pain? We can win over an individual only through our tenderly love and communication along with medical aid. Speak tenderly to the sick people. The reward will be paid by them through their gestures that will be double for all that you have done. If we observe in and around us, We can hear the helpless voice of the sick, they cry out, may be from their home, work place, hospital, old age homes and orphanages...etc. As health care professionals our responsibility is to prepare the way for the sick, help them to get adequate comfort in the respective areas.

Individuals who suffer from agony, pain, and discomfort should be made comfortable and shall be lifted up from their suffering. When we care for them, the uneven surfaces of the daily experiences shall become smooth once. The rough and tough experiences turn out to good and empowering experiences, and then the power of healing shall be revealed. All people will see it together and appreciate the presence and important and inevitable role of each health professionals, their work of mercy is like the flower of the field which will be seen by all. The weak and sick people will enjoy when they get the healing touch from them. Surely people will be empowered. The act of mercy will stand forever when the breath of the divine blows upon them.

We should awake from our sluggish actions and join our hands and raise out our voice with love and compassion and say to our fellow being, do not fear, we are here to consider and console you. Let us walk through the way of understanding; even though the sufferings are unavoidable. Stretch out our hands like a curtain and spreads them like a tent of comfort to live in. Then we can bring peace and serenity in their life and make them feel comfortable.

To whom we can compare the health team members? Their work of mercy is like an Angel's duty. We can't understand their ways, they are unreachable, their presence gives power to the weak and strengthens the powerless, let us renew their strength by giving motivation and allow them walk along with sick people and give them comfort in their sufferings. 